This is the peer reviewed version of the following article: Keen, Steve (2015) Post Keynesian Theories of Crisis. American Journal of Economics and Sociology, 74(2), pp. 298-324. ISSN (print) 0002-9246, which has been published in final form at http://dx.doi.org/10.1111/ajes.12099 . This article may be used for non-commercial purposes in accordance with Wiley Terms and Conditions for self-archiving.

http://olabout.wiley.com/WileyCDA/Section/id-817011.html 


\title{
Post Keynesian Theories of Crisis
}

\author{
By STEVE KeEN*
}

\begin{abstract}
Post Keynesian economics has two complementary theories of crisis that were used to predict the 2007 crisis and diagnose its causes: Minsky's financial instability hypothesis and Godley's stockflow-consistent approach. Both theories take a monetary perspective on capitalism and argue that the dynamics of private debt caused the crisis. As well as explaining the crisis and enabling its occurrence (though not precise timing) to be predicted, both theories imply that the current recovery will be short-lived because the underlying cause of the last crisis has not been addressed by subsequent economic policy.
\end{abstract}

Before the economic crisis in 2007, neoclassical economists were triumphant, confident that they had banished economic crises completely:

\begin{abstract}
Macroeconomics was born as a distinct field in the 1940's, as a part of the intellectual response to the Great Depression. The term then referred to the body of knowledge and expertise that we hoped would prevent the recurrence of that economic disaster. My thesis in this lecture is that macroeconomics in this original sense has succeeded: Its central problem of depression prevention has been solved, for all practical purposes, and has in fact been solved for many decades. (Lucas 2003: 1, emphasis added)
\end{abstract}

After the crisis, even staunch defenders of neoclassical methodology concede that it cannot explain crises: "The state of the art in macro can't generate financial crises yet" Yates (2014). Meanwhile, recent research papers express bemusement over the very fact of business cycles, let alone of serious financial crises:

One of the remarkable conundrums in theoretical economics is the socalled "business cycle," i.e. the existence of considerable, persistent

*Professor and Head, School of Economics, Politics, and History, Kingston University, London. Websites: www.debtdeflation.com/blogs; www.ideaeconomics.org. Author: Debunking Economics: The Naked Emperor Dethroned. Email: steve.keen@ kingston.ac.uk

American Journal of Economics and Sociology, Vol. 74, No. 2 (March, 2015).

DOI: 10.1111/ajes.12099

(C) 2015 American Journal of Economics and Sociology, Inc. 
fluctuations of the GDP, even for very large economies ... These fluctuations can culminate in crises, such as the most recent one of $2008 \ldots$ Naively, however, the output fluctuations of large economies should be very small. (Bonart et al. 2014: 1)

In contrast, Post Keynesian economics has at least two extant approaches to explain financial crises: Minsky's "Financial Instability Hypothesis"” and Godley's stock-flow-consistent method.

\section{Minsky's Financial Instability Hypothesis}

Minsky's objective in developing the "Financial Instability Hypothesis" was to meet his objective criteria for an adequate theory of economics:

"Can "It"-a Great Depression — happen again? And if "It" can happen, why didn't "It" occur in the years since World War II? These are questions that naturally follow from both the historical record and the comparative success of the past thirty-five years. To answer these questions it is necessary to have an economic theory which makes great depressions one of the possible states in which our type of capitalist economy can find itself. (Minsky 1982: xii, emphasis added)"

The development of Minsky's theory commenced with two factors that neoclassical economics ignores: 1) the existence of macroeconomic cycles and 2) private debt. He then posited a relationship between them. Whereas neoclassical economics argues that private debts are merely "pure redistributions" that "should have no significant macro-economic effects" (Bernanke 2000: 24), Minsky argued that the change in debt actually added to aggregate demand and aggregate income, an issue I return to later. He further posited a tendency for debt in a pure capitalist economy (one without a government sector) to rise relative to GDP over a number of business cycles, culminating in a debt level that caused a crisis like both the Great Depression and the 2007 "Global Financial Crisis."

Minsky's analysis was rooted in historical time, in sharp contrast to the ahistorical perspective of neoclassical economics. His instability hypothesis takes as its initial condition an economy that is experiencing tranquil growth after a recent economic crisis: 
The natural starting place for analyzing the relation between debt and income is to take an economy with a cyclical past that is now doing well. The inherited debt reflects the history of the economy, which includes a period in the not too distant past in which the economy did not do well.

Acceptable liability structures are based upon some margin of safety so that expected cash flows, even in periods when the economy is not doing well, will cover contractual debt payments. As the period over which the economy does well lengthens, two things become evident in board rooms. Existing debts are easily validated and units that were heavily in debt prospered; it paid to lever.

After the event it becomes apparent that the margins of safety built into debt structures were too great. As a result, over a period in which the economy does well, views about acceptable debt structure change. In the deal-making that goes on between banks, investment bankers, and businessmen, the acceptable amount of debt to use in financing various types of activity and positions increases. This increase in the weight of debt financing raises the market price of capital assets and increases investment. As this continues the economy is transformed into a boom economy. (Minsky 1982: 66, emphasis added)

This boom economy leads to the development of what Minsky (1982: 124, 123) called "euphoric expectations" in which banks "accept liability structures - their own and those of borrowers-that, in a more sober expectational climate, they would have rejected." This additional debt finance both accelerates the boom and sets up its ultimate failure. Many speculative ventures will receive funding, including ones Minsky referred to as "Ponzi finance" ventures, which lose money and rely upon continued debt finance to survive. The boom also changes many of the system states that enabled euphoric expectations to develop in the first place. Thus, a boom causes a rise in wages and in the cost of raw material and capital inputs to production.

Eventually, one or more of many factors conspire to end the boom. Those factors include: the failure of indebted and lossmaking entities to roll over their finance, market-driven increases in interest rates, the decline of corporate cash flows well below expectations as wage and other costs rise, and the crash of asset markets when indebted entities attempt to sell assets to meet financial commitments. While the boom developed gradually as memories of the 
previous crisis receded, Minsky (1982: 68) points out that the crash is sudden:

Whereas experimentation with extending debt structures can go on for years and is a process of gradual testing of the limits of the market, the revaluation of acceptable debt structures, when anything goes wrong, can be quite sudden.... High and rising interest rates can force hedge financing units into speculative financing and speculative financing units into Ponzi financing. Ponzi financing units cannot carry on too long. Feedbacks from revealed financial weakness of some units affect the willingness of bankers and businessmen to debt finance a wide variety of organizations. Unless offset by government spending, the decline in investment that follows from a reluctance to finance leads to a decline in profits and in the ability to sustain debt. Quite suddenly a panic can develop as pressure to lower debt ratios increases.

When the crash occurs, the economy is back in the situation that preceded the boom, with depressed economic activity, debt levels that are now seen as excessive, and stagnant investment. If it is still nonetheless possible for the majority of borrowers to service their debts-albeit at a reduced rate-then the economy can again enter the state that led to the previous boom, and boom once more. But each boom tends to start from a higher level of debt to GDP than the last, since borrowers undertake debt commitments during a boom and then find themselves having to service them during a slump — a pattern that leads to the debt ratio ratcheting up over time through a series of business cycles. Ultimately, however, a debt ratio is reached that results in debt servicing costs that exceed the cash flows of borrowers, which leads to unpaid debt being compounded and a runaway economic collapse as described by Fisher (1933), and as experienced in the Great Depression.

\section{Godley's Stock-Flow-Consistent Model: Predictions of Severe Recession}

Though Minsky employed Kaleckian identities in some of his papers, he largely abandoned the attempt to develop a mathematical expression of his hypothesis after his PhD thesis. In contrast, the other Post Keynesian approach, which originated in the work of Wynne Godley 
and Francis Cripp, was necessarily mathematical, in that it was based upon the accounting tautology that "every money flow comes from somewhere and goes somewhere."

Dividing the economy into sectors is a hallmark of the Post Keynesian approach to economics in general. Godley used this approach, and the availability of data on flows between these sectors, to assert that imbalances in inter-sectoral flows in the period after the 1990s recession ended could not be sustained, and therefore that a serious recession was imminent (Godley 2001, 1996; Godley and Izurieta 2002, 2004; Godley et al. 2005; Godley and Lavoie 2007; Godley and McCarthy 1998; Godley and Wray 2000). One conclusion that Godley derived from this approach stands in stark contrast to both Austrian and neoclassical approaches: he asserted that "expansionary fiscal policy is a necessary condition for growth in the long term" (Godley and McCarthy 1998: 39).

The logic behind this assertion can be demonstrated by the following thought experiment. Consider an economy that is growing (in both nominal and real terms), so that the total amount of money in the economy is growing. Divide it into three sectors - the private sector, the government, and the external sector-and consider the flows between these sectors. Though the total amount of money is growing, these flows sum to zero, since an outflow from one sector is an inflow into another. Assume that initially the external sector is balanced and, for simplicity, assume that the government only taxes and makes payments to the private sector.

If the government then decides to run a surplus - so that its tax receipts from the private sector exceed its payments to the private sector-then the private sector has to run a money deficit. Given the assumption of a growing economy in monetary terms, this also requires that the private sector can both produce the money the government surplus requires, and accumulate more money itself.

This raises the obvious question: How does the private sector "produce" money? The only means within the domestic economy itself is the endogenous creation of money by its banking subsector. ${ }^{1}$ As the Bank of England has recently emphasized (McLeay et al. 2014), banks create money by making loans: the loan increases the assets of the 
banking subsector and its liabilities as well, where those liabilities are the deposit accounts of the non-bank private sector.

Therefore, for the private sector to maintain the deficit required by the government sector's surplus, its non-bank subsector must borrow money sufficient to finance the government's surplus and to enable the economy to expand at the same time. So the corollary to a government running a sustained surplus and a growing economy is that the indebtedness of the non-bank private sector to the banking sector will grow faster than the economy itself grows.

The only other method to meet the twin requirements of an expanding economy and a sustained government surplus is for the external sector to be in surplus, so that net revenue from the rest of the world (when converted into local currency) enables the private sector to run a deficit with the government sector and to also accumulate more money. But this globally is a zero-sum game: the corollary of one country achieving this is that in sum all other countries must be running deficits.

What if these conditions cannot be met? What if the external sector is in fact in deficit, and the private non-bank subsector cannot borrow (or borrow enough) from the banking subsector to both finance the government surplus and increase the money supply? Then one or both of the initial assumptions must fail: either the government will fail to run a surplus, and/or the economy will contract in monetary terms. Therefore, the government needs to run a deficit in the long term if growth is to occur over the long term without leading to an unsustainable buildup of private debt. (The only remaining alternative - that real output rises while prices fall-has never happened in history, and is a logical chimera in a monetary economy with debt where deflation increases the debt burden.)

Godley's insight recasts the role of government from being "like a household" to being "like a bank." The "household" metaphor paraphrases the neoclassical and Austrian perspectives, according to which the government should either balance its books or run a surplus over the long term. By contrast, if the government functions more like a bank, there can be a long-term tendency to run a government deficit, thereby permitting the money supply to expand without relying completely on rising private-sector indebtedness. In the mixed privatepublic economy in which we actually live, a government deficit creates




\section{The American Journal of Economics and Sociology}

money in the same manner that a bank loan does-by net crediting the bank balances of the non-bank public_-but without the corollary of a private debt obligation that accompanies bank lending.

Unfortunately, this logic is far removed from the conventional belief that dominate parties of both the Right and the Left across the globe. They are misinformed by the fundamentally non-monetary principle of neoclassical economics that governments should either run balanced budgets over the long term, or even run a surplus. This belief dominated pre-crisis behavior by Western governments, so that they both aimed for and celebrated budget surpluses when they were achieved between 1992 and 2007. It has continued to inform post-crisis government policy, where the European Union is aiming for large government surpluses, and the political consensus in the Anglo-Saxon nations is that government debt must be reduced by running surpluses.

Given these policy fallacies, Godley concluded in 1998 that a contraction in the United States was inevitable because, since 1992, the United States ran a consistent current account deficit, and by 1998 the U.S. government was running sustained budget surpluses. With both the external sector and the government taking money out of the private sector, only one channel was left to provide the balancing flow: the banks. But this necessarily meant rising private-sector indebtedness over time, as shown above. The proposition that the growth in the indebtedness had to terminate at some point in the near future led to Godley's prediction that:

While another credit crunch like the one in 1991 is not inevitable, the average household debt-to-income ratio is now so high, and the servicing requirement already so burdensome, that one is bound to take seriously the possibility that the credit flow will at some point go abruptly into reverse ... the growth of net lending [by the banking sector to the private sector] cannot continue much longer. (Godley and McCarthy 1998: 52)

Godley's prediction, which was repeated and embellished with additional sectoral balance data in subsequent papers (Godley 2001; Godley and Izurieta 2002, 2004; Godley et al. 2005), stands out as the earliest warning of an impending crisis based on a causal factor that did manifest itself during the crisis: a collapse in net private-sector lending. This can be seen in Figure 1. 
Figure 1

Collapse in private-sector borrowing caused the crisis (Data sources follow the reference list at the end of this article.)

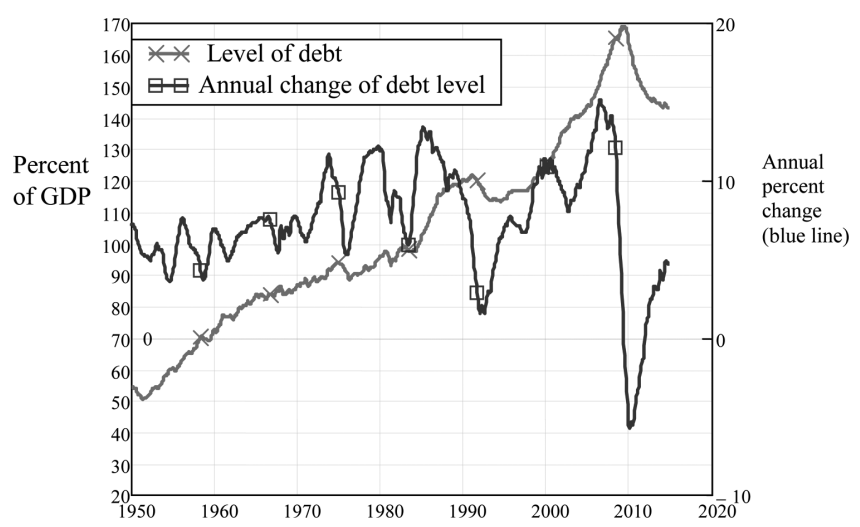

Modeling Minsky

I found Minsky's vision compelling when I first encountered it in 1987, and decided to attempt to model it in my PhD dissertation, using as my foundation Richard Goodwin's simple model of cyclical growth (Goodwin 1967). Goodwin's model was constructed on the basis of a number of stylized facts about the economy:

- The level of installed capital $(K)$, roughly speaking, determines the level of output $(Y=K / v$ where $\mathrm{v}$ is the capital to output ratio);

- The level of output, given labor productivity (a), determines the level of employment (L);

- The rate of employment $(\lambda=\mathrm{L} / \mathrm{N})$ determines the rate of change of real wages $(\mathrm{dw} / \mathrm{dt})$ via a Phillips Curve;

- In Goodwin's simple two-class model, output minus the wage bill ( $w . L$ ) determined profits ( $\Pi)$; and

- Profits determined gross investment (I), and gross investment minus depreciation $(\delta . K)$ is the rate of change of the capital stock $(\mathrm{dK} / \mathrm{dt})$. 


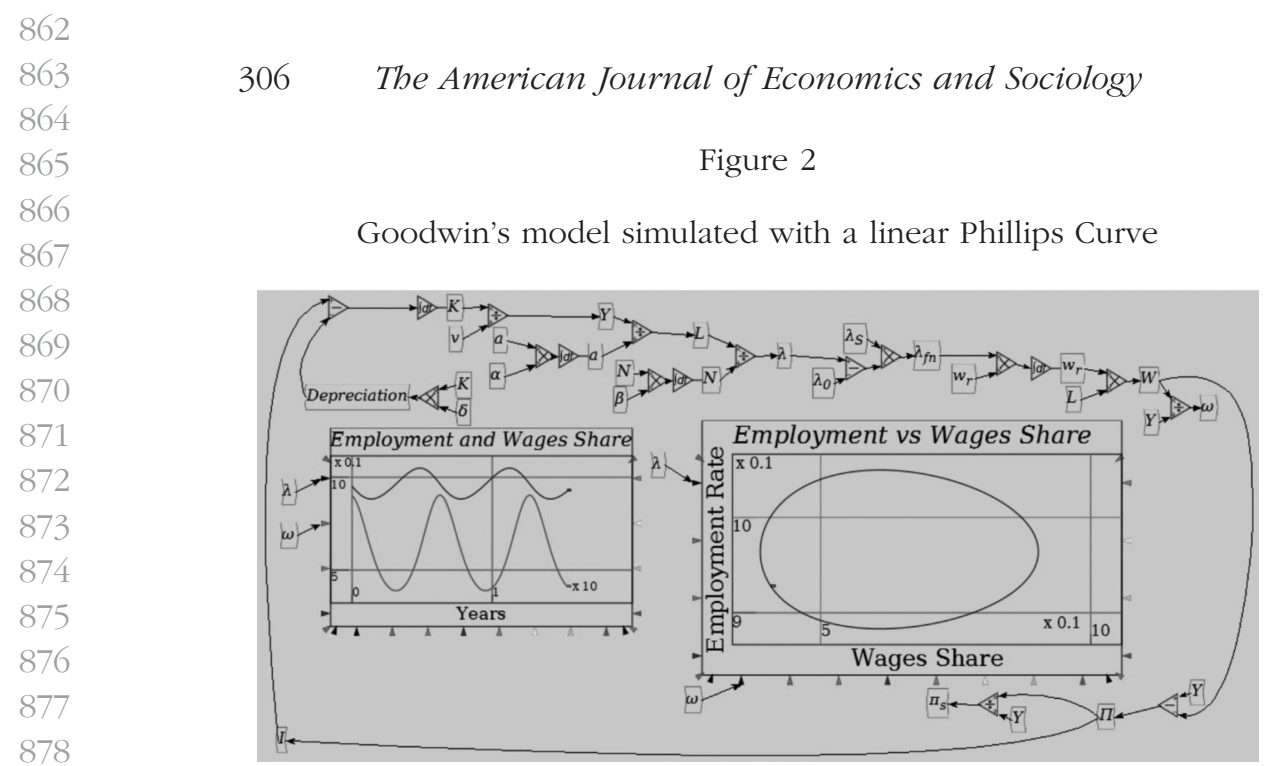

Using a linear specification for the Phillips Curve (see the Appendix for details), this generates the model shown in Figure 2. Cycles are endemic - the model's equilibrium is "marginally stable" in mathematical terms - and the realism of the cycles is increased if a nonlinear Phillips Curve is used. ${ }^{2}$ Though one paper claimed to find the model did not fit empirical data well (Harvie 2000), this result was based on simple errors in the econometrics, ${ }^{3}$ which, when corrected, revealed that the model fits OECD empirical data well (Grasselli and Maheshwari 2014). But the model omits a financial sector, and also assumes that all profits are invested.

I generalized this in order to model Minsky's hypothesis (Keen 1995) by arguing that firms invest less than profits during a slump, but more than profits during a boom, and finance the difference by taking on debt $(D)$ so that $(d D / d t=I-\Pi)$ - an assumption that was later confirmed in empirical work by Fama and French (1999a, 1999b, 2002): "Debt is indeed the residual variable in financing decisions" (Fama and French 2002: 30). To do so, I introduced a nonlinear investment function, and a matching nonlinear Phillips Curve mechanism, following Blatt (1983).

This resulted in a model that, though not fitted to empirical data, reproduced the stylized facts of the 1990s and 2000s: a period of reduced volatility in unemployment and inflation (the so-called Great 
Goodwin's model with debt: A "Great Moderation" followed by breakdown

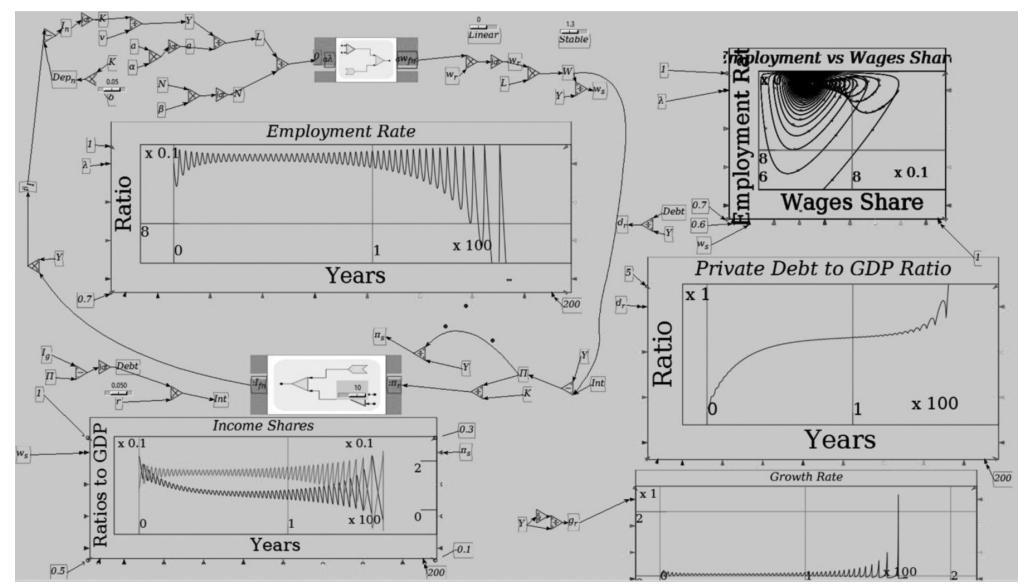

Moderation): (see Bernanke 2004a, 2004b). As Figure 3 shows, this was accompanied by a rising ratio of private debt to GDP and increasing inequality (fall in workers' share of GDP). This is followed by increasing volatility in employment for the final two-thirds of the simulation, with the debt-to-GDP ratio rising in a series of humps. The simulation ends with an economic crisis in which employment falls to zero, and the debt-to-GDP ratio increases without limit.

These characteristics were endemic to the model-regardless of the functional forms used for the Phillips Curve or the investment function (Grasselli and Costa Lima 2013), implying that this is a simple consequence of including the reality of debt-financed investment in a cyclical model of the economy.

Though the eventual crisis and the cyclical-secular increase in the private debt to GDP ratio were predictions of Minsky's verbal model, the declining volatility (and declining workers' share of output) prior to the crisis was not, and I therefore finished this paper-which was written in 1992, though published in 1995-with what I thought was a nice rhetorical flourish: 
308 The American Journal of Economics and Sociology

From the perspective of economic theory and policy, this vision of a capitalist economy with finance requires us to go beyond that habit of mind that Keynes described so well, the excessive reliance on the (stable) recent past as a guide to the future. The chaotic dynamics explored in this paper should warn us against accepting a period of relative tranquility in a capitalist economy as anything other than a lull before the storm. (Keen 1995: 634)

Other research activities (Keen, 2001, 2004, 2005b) distracted me from this issue between 1999 and 2005, but in December 2005, I was required to testify as an expert witness in an Australian court case over predatory lending (Keen 2005a). I consulted the empirical data on private debt in Australia and the United States as shown in Figure 4. From those data, I concluded that the crisis my model generated was about to occur in the real world.

Given the time lags in academic publishing, from December 2005 I issued warnings of an impending crisis via mainstream and social media. A blog post (Keen 2007) provides a typical statement:

So how do I justify the stance of a Cassandra? Because things can't continue as normal, when normal involves an unsustainable trend in debt. At some point, there has to be a break-though timing when that break will occur is next to impossible, especially so when it depends in part on individual decisions to borrow.... The debt to GDP ratio must stabilise - and on past trends, it won't stop simply at stabilising. When that inevitable reversal of the unsustainable occurs, we will have a recession.

\section{Change in Debt and Macroeconomics: The Empirical Data}

Mainstream economics ignored the debt buildup on the basis of the empirically false "loanable funds" model of banking (McLeay, Radia, and Thomas 2014). According to that model, which was criticized by Irving Fisher in the 1930s, private debt is regarded as simply redistributing spending power from lender to borrower:

Fisher's idea was less influential in academic circles, though, because of the counterargument that debt-deflation represented no more than a redistribution from one group (debtors) to another (creditors). Absent implausibly large differences in marginal spending propensities among 
Figure 4

Private debt to GDP ratios in Australia and the United States

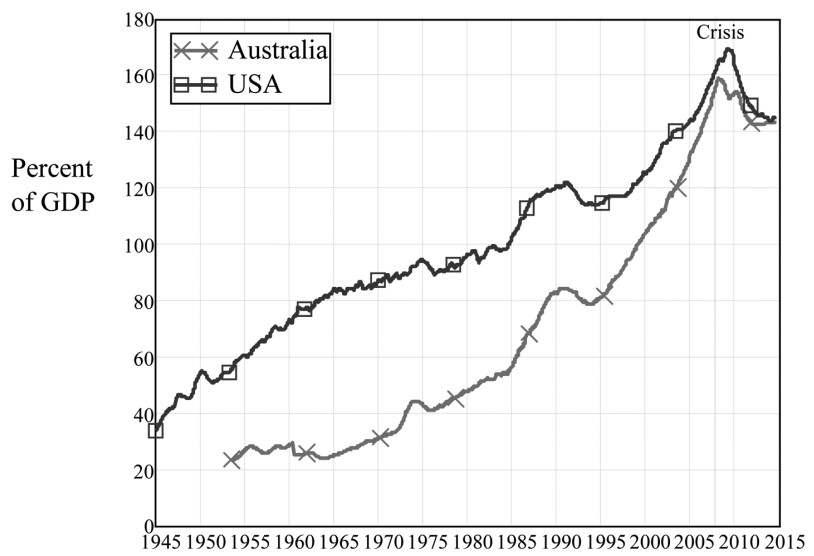

the groups, it was suggested, pure redistributions should have no significant macro-economic effects. (Bernanke 2000: 24)

In contrast, following Minsky (1963, 1982: 5-6, 1975: 132-133), Schumpeter (1934: 106), Fisher (1932) and many other non-neoclassical authors, I argued that the change in debt contributed to aggregate demand, since in the real world of endogenous money - in which bank lending creates bank deposits that are then spent by the borrowerthere is no offsetting decrease in spending power by a bank when it makes a loan. Though developing a logical proof of this intuition took time (see the next section of this article), the empirical support I found for the hypothesis was overwhelming: the correlation of the change in private debt with unemployment from 1990 till 2014 is -0.93 (see Figure 5 ), and the correlation of the acceleration of private debt with change in unemployment is -0.89 (see Figure 6). ${ }^{4}$

The crisis commenced in August $2007^{5}$ when the rate of growth of private debt abruptly plummeted, bringing "The Great Moderation" to a sudden and ignominious end as unemployment rose rapidly, and inflation briefly gave way to deflation (see Figure 7 ). 
U.S. change in debt inversely correlated (-0.93) with unemployment (Data sources follow the reference list at the end of this article.)

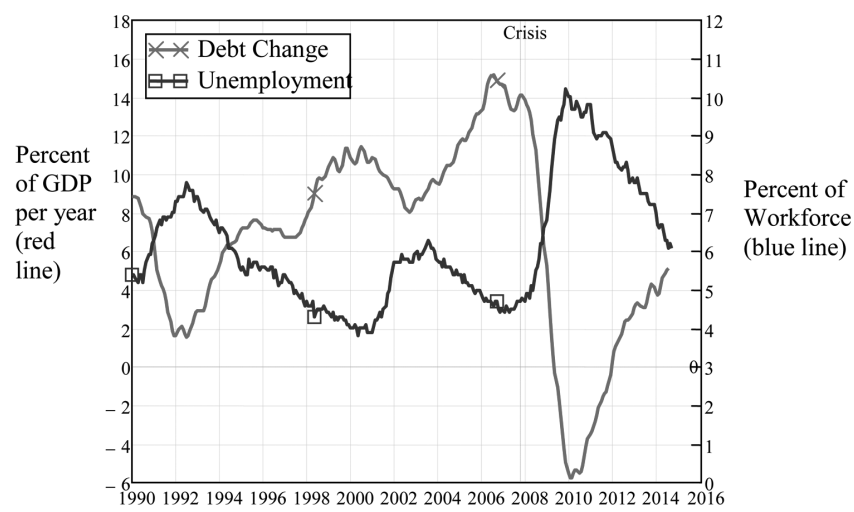

\section{Change in Debt and Macroeconomics: The Logical Case}

Though Fisher (1932), Schumpeter (1934), and many Post Keynesians_-in particular Minsky, but also Moore (1988) and Eichner (1987) have argued that the change in debt plays a significant role in aggregate demand, the proposition was rejected by many other Post Keynesians on the grounds that expenditure is income: one person's expenditure becomes someone else's income. This tautological identity, it was thought, left no role in macroeconomics for changes in aggregate private debt-a conclusion that was consistent with the neoclassical perspective, even though the two models of money are completely different.

In fact, the tautology that income is expenditure can be reconciled with the change in debt playing a role in both aggregate demand and aggregate income. Consider a three-sector model of a pure private monetary economy in which expenditure can be financed either out of the existing stock of money, or out of new money generated by an increase in debt. The intersectoral flows can be represented in a table in which the columns represent net income for each sector, and the rows represent expenditure by each sector. The negative of the sum of the diagonals represents aggregate demand, while the sum of the off-diagonal elements represents aggregate 
Figure 6

Accelerating debt in the United States reduces unemploymen

income. Aggregate demand and aggregate income are necessarily equal, and the sum of all the elements in the table is necessarily zero.

Expenditure by sector $\boldsymbol{x}$ to purchase output from sector $\boldsymbol{y}$ using existing money is signified by $\boldsymbol{E}_{\boldsymbol{x y y}}$. Expenditure financed by a change in debt is signified by $\Delta \boldsymbol{D}$ in the case of a single instance of borrowing, and by $\frac{d}{d t} D$ when there is a flow of new lending over time. The hypothetical situation in which no borrowing is possible is shown in Table 1.

Equation (1.1) shows aggregate demand $\boldsymbol{A D}_{\boldsymbol{A}}$ and aggregate income $\boldsymbol{A} \boldsymbol{Y}_{\boldsymbol{A}}$ for Case A.

$$
\begin{gathered}
A D_{A}=\left(E_{1,2}+E_{1,3}\right)+\left(E_{2,1}+E_{2,3}\right)+\left(E_{3,1}+E_{3,2}\right) \\
A Y_{A}=E_{1,2}+E_{1,3}+E_{2,1}+E_{2,3}+E_{3,1}+E_{3,2}
\end{gathered}
$$

Now consider a single loan from sector 2 to sector 1 of $\Delta \boldsymbol{D}$, which is immediately spent in the proportions $\alpha$ and $(\mathbf{1}-\alpha)$, respectively, on the outputs of sectors 2 and 3. This loan reduces sector's 2's spending capacity by the same amount, and this reduced spending capacity is 


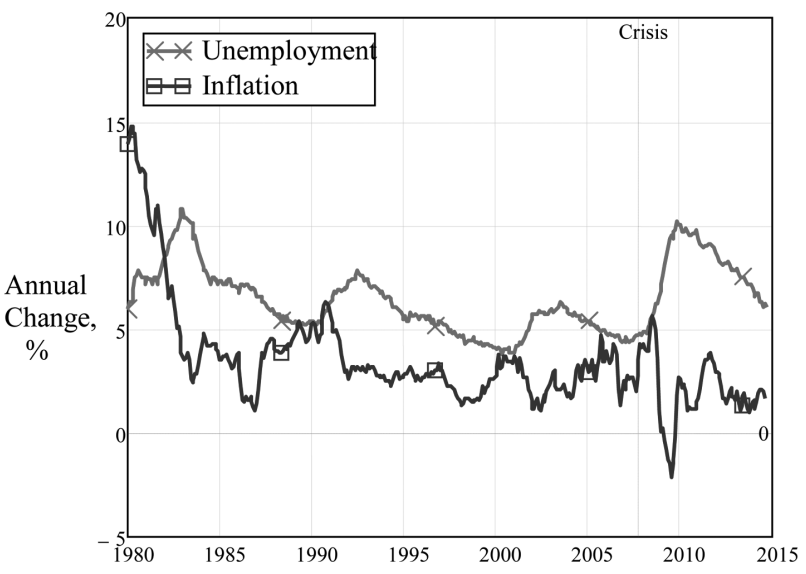

shared in the proportions $\beta$ and $(\mathbf{1}-\beta)$, respectively, in sector 2's expenditure upon sectors 1 and 3 .

Equation (1.2) shows aggregate demand and aggregate income in this system:

$$
\begin{gathered}
A D_{B}=\left(E_{1,2}+E_{1,3}\right)+\left(E_{2,1}+E_{2,3}\right)+\left(E_{3,1}+E_{3,2}\right) \\
A Y_{B}=E_{1,2}+E_{1,3}+E_{2,1}+E_{2,3}+E_{3,1}+E_{3,2}
\end{gathered}
$$

Thus in Case B, aggregate expenditure is aggregate income.

Now consider Table 3, in which sector 1 borrows the amount $\Delta \boldsymbol{D}$ from the banking sector (not shown here).

In this situation, both aggregate demand and aggregate income are boosted by the amount $\boldsymbol{\Delta D}$ :

$$
\begin{aligned}
& A D_{C}=\Delta D+\left(E_{1,2}+E_{1,3}\right)+\left(E_{2,1}+E_{2,3}\right)+\left(E_{3,1}+E_{3,2}\right) \\
& A Y_{C}=\Delta D+\left(E_{1,2}+E_{1,3}\right)+\left(E_{2,1}+E_{2,3}\right)+\left(E_{3,1}+E_{3,2}\right)
\end{aligned}
$$

Thus given the endogenous creation (or destruction) of money by the banking sector, aggregate demand equals demand generated out of 
Table 1

No borrowing or lending is possible (Case A)

\begin{tabular}{lccc}
\hline Activity $\backslash$ Sector & Sector 1 & Sector 2 & Sector 3 \\
\hline Sector 1 & $-\left(\mathrm{E}_{1,2}+\mathrm{E}_{1,3}\right)$ & $\mathrm{E}_{1,2}$ & $\mathrm{E}_{1,3}$ \\
$\quad$ Expenditure & $\mathrm{E}_{2,1}$ & $-\left(\mathrm{E}_{2,1}+\mathrm{E}_{2,3}\right)$ & $\mathrm{E}_{2,3}$ \\
$\begin{array}{l}\text { Sector 2 } \\
\text { Expenditure }\end{array}$ & $\mathrm{E}_{3,1}$ & $\mathrm{E}_{3,2}$ & $-\left(\mathrm{E}_{3,1}+\mathrm{E}_{3,2}\right)$ \\
$\begin{array}{l}\text { Sector 3 } \\
\text { Expenditure }\end{array}$ & & & \\
\hline
\end{tabular}

the turnover of existing money, plus demand generated by the creation of new money through the change in debt, and this causes an equivalent change in aggregate income.

Now consider a continuous flow of lending from the banking sector of $\frac{d}{d t} D$, where this borrowed money is spent in the proportions $\alpha$ and $(\mathbf{1}-\alpha)$ as before. Since interest payments now go from sector 1 to the banking sector, an additional column $\boldsymbol{B}_{\boldsymbol{E}}$ ("Bank Equity") is added, into which interest payments are made. The existing stocks of money ( $\boldsymbol{S}_{\mathbf{1}}$, $\boldsymbol{S}_{\mathbf{2}}$, and $\boldsymbol{S}_{\mathbf{3}}$ ) are treated as bank deposits, so deposit interest is payable on them at the rate $\boldsymbol{r}_{\boldsymbol{D}}$ from the account $\boldsymbol{B}_{\boldsymbol{E}}$. For simplicity, sectors 1 to

Table 2

Borrowing and lending between sectors occurs (Case B: Loanable Funds)

\begin{tabular}{lccc}
\hline Activity $\backslash$ Sector & Sector 1 & Sector 2 & Sector 3 \\
\hline Sector 1 & $-\left(\left[\mathrm{E}_{1,2}+\alpha \cdot \Delta \mathbf{D}\right]\right.$ & $\mathrm{E}_{1,2}$ & $\mathrm{E}_{1,3}$ \\
Expenditure & $+\left[\mathrm{E}_{1,3}\right.$ & $+\alpha_{\mathbf{.}} \Delta \mathbf{D}$ & $+(\mathbf{1}-\boldsymbol{\alpha}) \cdot \Delta \mathbf{D})$ \\
& $+(\mathbf{1}-\alpha) \cdot \Delta \mathbf{D}])$ & & \\
Sector 2 & $\mathrm{E}_{2,1}-\beta . \Delta \mathbf{D}$ & $-\left(\left[\mathrm{E}_{2,1}-\beta \cdot \Delta \mathbf{D}\right]\right.$ & $\mathrm{E}_{2,3}$ \\
Expenditure & & $+\left[\mathrm{E}_{2,3}\right.$ & $-(\mathbf{1}-\beta) \cdot \Delta \mathbf{D}]$ \\
Sector 3 & & $-(\mathbf{1}-\beta) \cdot \Delta \mathbf{D}])$ & \\
$\quad$ Expenditure & $\mathrm{E}_{3,1}$ & $\mathrm{E}_{3,2}$ & $-\left(\mathrm{E}_{3,1}+\mathrm{E}_{3,2}\right)$ \\
\hline
\end{tabular}


The American Journal of Economics and Sociology

Borrowing from and lending by banks occurs (Case C: Endogenous Money)

\begin{tabular}{lccc}
\hline Activity $\backslash$ Sector & Sector 1 & Sector 2 & Sector 3 \\
\hline Sector 1 & $-\left(\left[\mathrm{E}_{1,2}+\alpha \cdot \mathbf{\Delta D}\right]+\right.$ & $\mathrm{E}_{1,2}+$ & $\mathrm{E}_{1,3}+$ \\
Expenditure & {$\left[\mathrm{E}_{1,3}+\right.$} & $\boldsymbol{\alpha} \cdot \mathbf{\Delta} \mathbf{D}$ & $\mathbf{( 1 - \alpha ) \cdot \boldsymbol { \Delta } \mathbf { D }}$ \\
& $(\mathbf{1}-\alpha) \cdot \boldsymbol{\Delta} \mathbf{D}])$ & & \\
Sector 2 & $\mathrm{E}_{2,1}$ & $-\left(\mathrm{E}_{2,1}+\right.$ & $\mathrm{E}_{2,3}$ \\
$\quad$ Expenditure & & $\left.\mathrm{E}_{2,3}\right)$ & \\
Sector 3 & $\mathrm{E}_{3,1}$ & $\mathrm{E}_{3,2}$ & $-\left(\mathrm{E}_{3,1}\right.$ \\
Expenditure & & & $\left.+\mathrm{E}_{3,2}\right)$ \\
\hline
\end{tabular}

3 are shown as not buying anything from $\boldsymbol{B}_{\boldsymbol{E}}$, while $\boldsymbol{B}_{\boldsymbol{E}}$ buys from all three sectors at the rates $\tau_{\mathbf{B} 1}, \tau_{\mathbf{B} \mathbf{2}}$, and $\tau_{\mathbf{B} 3}$, respectively. Flow rates, $\tau_{\mathbf{x y}}$ (where $\tau_{\mathbf{x y}}$ is a time constant, dimensioned in dollars per year), are used to describe the flow of expenditure out of existing money stocks.

Equation (1.4) shows the resulting outcomes for aggregate demand and aggregate income.

$$
\begin{gathered}
A D_{E M}=\left(\frac{1}{\tau_{1,2}}+\frac{1}{\tau_{1,3}}\right) \cdot S_{1}+\left(\frac{1}{\tau_{2,1}}+\frac{1}{\tau_{2,3}}\right) \cdot S_{2}+\left(\frac{1}{\tau_{3,1}}+\frac{1}{\tau_{3,2}}\right) \cdot S_{3} \\
+\left(\frac{1}{\tau_{B, 1}}+\frac{1}{\tau_{B, 2}}+\frac{1}{\tau_{B, 3}}\right) \cdot B_{E} \\
+r_{D} \cdot\left(S_{1}+S_{2}+S_{3}\right)+r_{L} \cdot D+\frac{d}{d t} D \\
A Y_{E M}=\left(\frac{1}{\tau_{1,2}}+\frac{1}{\tau_{1,3}}\right) \cdot S_{1}+\left(\frac{1}{\tau_{2,1}}+\frac{1}{\tau_{2,3}}\right) \cdot S_{2}+\left(\frac{1}{\tau_{3,1}}+\frac{1}{\tau_{3,2}}\right) \cdot S_{3} \\
+\left(\frac{1}{\tau_{B, 1}}+\frac{1}{\tau_{B, 2}}+\frac{1}{\tau_{B, 3}}\right) \cdot B_{E} \\
+r_{D} \cdot\left(S_{1}+S_{2}+S_{3}\right)+r_{L} \cdot D+\frac{d}{d t} D
\end{gathered}
$$

Thus, in a purely private-sector monetary economy, aggregate demand and aggregate income include expenditure financed by existing money 
1834

1836 
The American Journal of Economics and Sociology

Figure 8

Annual \% change in ratio of private sector debt to GDP

Releveraging in the United States versus austerity-driven deleveraging in Europe

(Data sources follow the reference list at the end of this article.)

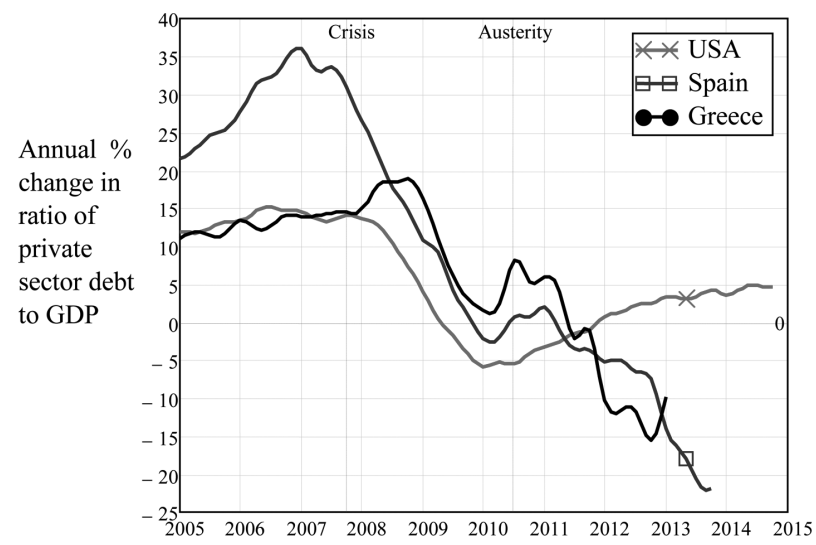

(the first four terms in each equation in Equation (1.4)), plus gross financial transactions (the next two terms) and the change in debt (the final term). At the aggregate level, the flow terms can be collapsed into an aggregate velocity of money $\mathrm{V}$ and an aggregate money stock $\mathrm{M}$ - yielding the first term in Friedman's model of monetarism (minus the empirically false assertion that velocity is constant). The endogenous money generalization of Friedman's equation is given by Equation (1.5).

$$
A D_{E M}=A Y_{E M}=V \cdot M+\frac{d}{d t} D+r_{D} \cdot M+r_{L} \cdot D
$$

When the rate of change of aggregate demand and aggregate expenditure are considered, this results in Equation (1.6), which includes a term for the acceleration of debt (the other terms in the expansion are omitted for brevity):

$$
\frac{d}{d t} A D_{E M}=\frac{d}{d t} A Y_{E M} \approx M \cdot \frac{d}{d t} V+V \cdot \frac{d}{d t} D+\frac{d^{2}}{d t^{2}} D
$$

Equations (1.5) and (1.6) explain the extremely high correlations shown between the change in debt and the level of unemployment 
Figure 9

U.S. private debt as percent of GDP since 1834

\section{Conclusion}

Debt as $\%$

of GDP

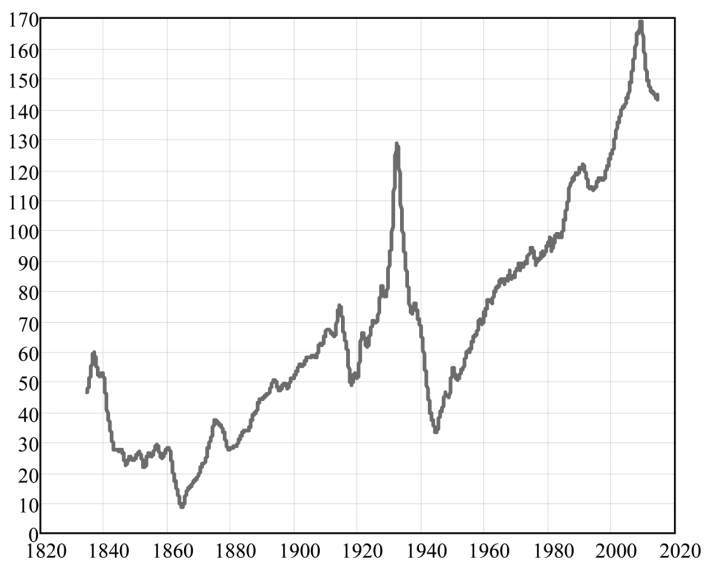

and the acceleration of debt and the change in unemployment shown in Figure 5 and Figure 6.

Post Keynesian theory had two compatible theories of crisis, which were empirically vindicated not only by the crisis but also by the "Great Moderation" boom that preceded it. These theories have been more tightly integrated since the crisis, though the development of a complete model is still ongoing.

The prognosis these theories give for the current recovery is not a healthy one. The recovery in the United States was initiated by the huge increase in the government deficit, which both enabled the money supply to expand despite private-sector deleveraging and a continuing current account deficit, and that encouraged the private sector to start leveraging once more. Policy in the United States stands in stark contrast to the effect of austerity policies in Europe. As Figure 8 shows, private debt is now rising at a rate of 5 percent per year in the United States, while it is falling at more than 10 percent of GDP per annum in the worst affected economies in Europe. ${ }^{6}$ 
That is the good news for the American economy. The bad news is that this current revival is commencing from an unprecedented level of private debt, because the deleveraging that occurred during the crisis was quite limited compared to that after the Great Depression, as shown in Figure 9.

The recovery is therefore likely to be very short-lived, since within a few years the debt servicing burden is likely to lead the private sector to cease borrowing once more, thus terminating the debt-driven boost to aggregate demand and triggering another recession. This is especially likely if the political obsession with achieving a government budget surplus reasserts itself.

\section{Notes}

1. Editor's note: The "endogenous creation of money" refers to a central concept in Post Keynesian economics, namely, that the creation of money occurs as a result of the expansion of economic activity. Money (as distinct from government-issued currency) comes into being only when there is demand for it, that is, when someone borrows it. The central bank can influence the money supply, but it cannot control it. Interest rates are not set by the intersection of the supply and demand for money because supply and demand are not independent variables. For the same reason, price inflation is not created primarily or exclusively by expansion of the money supply, but rather by factors that diminish productivity.

2. For discussion of the mathematics of economic stability, see http://en. wikipedia.org/wiki/Marginal_stability.

3. Confirmed by my own research and personal correspondence with Harvie.

4. Editor's note: To paraphrase the author here, debt generates economic growth, so when private borrowing stimulates the economy, the unemployment rate declines. Figure 6 makes this correlation particularly obvious by inverting the scale by which changes in unemployment are represented.

5. BBC News (2009) reported: "The start of the phenomenon has been pinpointed as 9 August 2007 when bad news from French bank BNP Paribas triggered sharp rise in the cost of credit, and made the financial world realise how serious the situation was" (BBC News 2009). The Guardian (2011) reiterated this point: "Phase one on 9 August 2007 began with the seizure in the banking system precipitated by BNP Paribas announcing that it was ceasing activity in three hedge funds that specialised in US mortgage debt. This was the moment it became clear that there were tens of trillions of dollars worth of dodgy derivatives swilling round which were worth a lot less than the bankers had previously imagined." 
6. Editor's note: The author refers in the text and in Figure 8 to "deleveraging." Since leverage is the process of using a small asset base to create a larger supply of money (credit) by borrowing, the term "deleveraging" refers to the reverse process whereby money or credit is destroyed as loans are paid off more rapidly than new debt is incurred.

\section{References}

BBC News. (2009). "Timeline: Credit Crunch to Downturn." August 7. $<$ http://news.bbc.co.uk/2/hi/7521250.stm>

Bernanke, Ben S. (2000). Essays on the Great Depression. Princeton: Princeton University Press.

- (2004a). The Great Moderation: Remarks by Governor Ben S. Bernanke at the Meetings of the Eastern Economic Association, Washington, DC, February 20, 2004. Washington, DC: Federal Reserve Board. <http://www.federalreserve.gov/boarddocs/speeches/2004/20040220/>

—. (2004b). "Panel Discussion: What Have We Learned Since October 1979?" In Conference on Reflections on Monetary Policy 25 Years After October 1979. St. Louis, MO: Federal Reserve Bank of St. Louis.

Blatt, John M. (1983). Dynamic Economic Systems: A Post-Keynesian Approach. Armonk, NY: M.E. Sharpe.

Bonart, Julius, Jean-Philippe Bouchaud; Augustin Landier, and David Thesmar. (2014). "Instabilities in Large Economies: Aggregate Volatility Without Idiosyncratic Shocks," In arXiv.org: Cornell University. arXiv:1406.5022.

Eichner, A. S. (1987). The Macrodynamics of Advanced Market Economies. Armonk: M.E. Sharpe.

Fama, Eugene F. and Kenneth R. French. (1999a). "The Corporate Cost of Capital and the Return on Corporate Investment." Journal of Finance 54(6): 1939-1967.

(1999b). "Dividends, Debt, Investment, and Earnings." In Working Papers. University of Chicago.

_. (2002). "Testing Trade-Off and Pecking Order Predictions About Dividends and Debt." Review of Financial Studies 15(1): 1-33.

Fisher, Irving. (1932). Booms and Depressions: Some First Principles. New York: Adelphi.

— . 1933. "The Debt-Deflation Theory of Great Depressions." Econometrica 1(4): 337-357.

Godley, Wynne. (2001). "The Developing Recession in the United States." Banca Nazionale del Lavoro Quarterly Review 54(219): 417-425.

. 1996. "Money, Finance and National Income Determination: An Integrated Approach." Working Paper No. 167. Levy Economics Institute of Bard College. <http://www.levyinstitute.org/pubs/wp/167.pdf> 
Godley, Wynne and Alex Izurieta. (2002). "The Case for a Severe Recession." Challenge 45(2): 27-51.

. (2004). "The US Economy: Weaknesses of the 'Strong' Recovery." Banca Nazionale del Lavoro Quarterly Review 57(229): 131-139.

Godley, Wynne, Alex Izurieta, H. Peter Gray, and John R. Dilyard. (2005). "Strategic Prospects and Policies for the U.S. Economy." In Globalization and Economic and Financial Instability. Eds. H. P. Gray and J. R. Dilyard, pp. 431-459. Cheltenham, UK: Elgar.

Godley, Wynne and Marc Lavoie. (2007). "Fiscal Policy in a Stock-Flow Consistent (Sfc) Model." Journal of Post Keynesian Economics 30(1): 79-100.

Godley, Wynne and George McCarthy. (1998). "Fiscal Policy Will Matter." Challenge 41(1): 38-54.

Godley, Wynne and L. Randall Wray. (2000). "Is Goldilocks Doomed?" Journal of Economic Issues 34(1): 201-206.

Goodwin, Richard M. (1967). "A Growth Cycle." In Socialism, Capitalism and Economic Growth. Ed. C. H. Feinstein, pp. 54-58. Cambridge: Cambridge University Press.

Grasselli, M. and B. Costa Lima. (2013). "An Analysis of the Keen Model for Credit Expansion, Asset Price Bubbles and Financial Fragility." Mathematics and Financial Economics 6: 191-210.

Grasselli, M. and Aditya Maheshwari. (2014). Testing Goodwin Growth Cycles. Toronto: Fields Institute.

Guardian, The. (2011). "Global Financial Crisis: Five Key Stages 2007-2011." August 7. <http://www.theguardian.com/business/2011/aug/07/globalfinancial-crisis-key-stages $>$

Harvie, David. (2000). "Testing Goodwin: Growth Cycles in Ten OECD Countries." Cambridge Journal of Economics 24(3): 349-376.

Keen, Steve. (1995). "Finance and Economic Breakdown: Modeling Minsky's 'Financial Instability Hypothesis'." Journal of Post Keynesian Economics 17(4): 607-635.

- (2001). Debunking Economics: The Naked Emperor of the Social Sciences. Sydney \& London: Pluto Press Australia \& Zed Books UK.

—. (2004). "Improbable, Incorrect or Impossible? The Persuasive But Flawed Mathematics of Microeconomics." In A Guide to What's Wrong with Economics. Ed. E. Fullbrook, pp. 209-222. London: Anthem Press.

(2005a). "Expert Opinion, Permanent Mortgages vs Cooks." Sydney: Legal Aid NSW. <http://www.debtdeflation.com/blogs/wp-content/ uploads/2007/04/KeenOpinionPonziLoans.pdf $>$ . (2005b). "Why Economics Must Abandon its Theory of the Firm." In Economics: Complex Windows. Ed. M. Salzano and A. Kirman, pp. 65-88. New Economic Windows series. Milan and New York: Springer. 


\section{Data Sources}

\section{Figure 1: Collapse in private sector borrowing caused the crisis}

US debt data since 1945 is sourced from the Federal Reserve Financial Accounts of the United States (<http://www.federalreserve.gov/ releases/z1/Current/ $>$ ). Private sector debt in Figure 1 is defined as the sum of Household (FL154104005), Nonfinancial Corporate (FL104104005) and Nonfinancial Non-corporate (FL114104005) debt. See <http://www. federalreserve.gov/releases/z1/Current/Coded/coded.pdf $>$ for the data codes and < http://www.federalreserve.gov/releases/z1/Current/Disk/ ltabs.zip $>$ for the data.

Nominal GDP is sourced from the Bureau of Economic Analysis (<www.bea.gov $>$ ). The data file is located at <www.bea.gov/ national/xls/gdplev.xls $>$.

Figure 4: Private debt to GDP ratios in Australia and the United States

US Debt and nominal GDP data is as for Figure 1. Australian private sector debt is sourced from the Reserve Bank of Australia (<http:// 
www.rba.gov.au/statistics/tables/index.html $>$ Table D02 Column I) for post-1976 data and <http://www.rba.gov.au/statistics/xls/op8/3-2. xls $>$ (Column AM) for pre-1976 data.

Figure 5: U.S. change in debt inversely correlated (-0.93) with unemployment

US Debt and nominal GDP data is as for Figure 1. Unemployment data is sourced from the Bureau of Labor Statistics < http://data.bls.gov/ cgi-bin/surveymost?bls $>$ (Series LNS14000000).

Figure 6: Accelerating debt in the U.S. reduces unemployment

US Debt and nominal GDP data is as for Figure 1. Debt acceleration is defined as the change in the change in debt over a year, divided by GDP. Unemployment data is as for Figure 5. Change in unemployment is defined as the percentage change in unemployment over a year.

\section{Figure 7: U.S. Unemployment and Inflation Rates}

Unemployment data is as for Figure 5. CPI data is from <http://data. bls.gov/cgi-bin/surveymost?cu > (Series CUUR0000SA0). Inflation is the annual percentage change in the CPI index.

Figure 8: Releveraging in the U.S. versus austerity-driven deleveraging in Europe

US Debt and nominal GDP data is as for Figure 1. Greece and Portugal private sector debt are sourced from the Bank of International Settlements "Long series on credit to the private non-financial sector" (<http://www.bis.org/statistics/credtopriv.htm $>$ ). The precise query to retrieve the data used here is <http://stats.bis.org/bis-stats-tool/org.bis. stats.ui.StatsApplication/StatsApplication.html?query=eJxNjFsKAjEMRW 9lfKLgBpy9pG0GZ6gW20jxK7txBa7GtbgYox9iIDn3ELiAm\%2B7984C9 H2tjr4GkhiOfGL1pFVOVLJQ0FI6jaCShIeUGmzmwfBhXxpdx4Zxdh24 ofPkm9wFmth12PpeSG5eqQW7YSNDE52iOreXfF2szitO1yl\%2FbG6c $\mathrm{BICk} \% 3 \mathrm{D}>$.

\section{Figure 9: US Private debt as percent of GDP since 1834}

Post-1945 debt data is as for Figure 1. Data from 1834 till 1945 is from two tables in the US Census document, Historical Statistics of the United States, Colonial Times to 1970: <http://www2.census.gov/prod2/ statcomp/documents/CT1970p2-11.pdf >: Series X 393-409 for data from 1916 till 1970; and Series X 580-587 for data from 1834 till 1970. Total loans data (Series X 582) was used to derive the composite series for the years from 1834 till 1929, while the individual, farm, nonfarm 
mortgage and other nonfarm data (Series X 402) were used to derive a household debt data series from 1916 till 1945, and Series X 399 was used for a nonfinancial business debt data series. These were then normalized to match the Federal Reserve data series from 1945 on. Nominal GDP data was sourced from the Measuring Worth project: <http:// www.measuringworth.com/usgdp/\#>.

\section{Appendix}

The basic Goodwin model in Figure 2 with a linear Phillips Curve

$\frac{d K}{d t}=I-K \times \delta$

$\frac{d w_{r}}{d t}=\lambda_{\mathrm{fn}} \times w_{r}$

$\lambda_{\mathrm{fn}}=\lambda_{S} \times\left(\lambda-\lambda_{0}\right)$

$Y=\frac{\mathrm{K}}{v}$

$L=\frac{Y}{\mathrm{a}}$

$\lambda=\frac{L}{\mathrm{~N}}$

$W=\mathrm{W}_{r} \times L$

$I=\Pi$

$\Pi=Y-W$

$\frac{d N}{d t}=N \times \beta ; \beta=0.01$

$\frac{d a}{d t}=a \times \alpha ; \alpha=0.02$

$\lambda_{0}=0.96 ; \lambda_{S}=5 ; \mathrm{v}=3 ; \delta=0.1$

$\mathrm{K}(0)=300 ; \mathrm{w}_{r}(0)=0.9 ; \mathrm{N}(0)=105 ; \mathrm{a}(0)=1$

Additional and altered equations from Goodwin model in the Minsky model in Figure 3 
The American Journal of Economics and Sociology

$$
\begin{gathered}
\frac{d \text { Debt }}{d t}=I_{g}-\Pi \\
\Pi=Y-(W+r \times \text { Debt }) \\
\frac{d w_{r}}{d t}=w_{\mathrm{fn}} \times w_{r} \\
w_{\mathrm{fn}}=\left(\frac{A}{(B-C \times \lambda)^{2}}-D\right) \\
I_{\mathrm{fn}}=\left(\frac{E}{\left(F-G \times \pi_{r}\right)^{2}}-H\right)
\end{gathered}
$$

$$
\alpha=0.025 ; \beta=0.02 ; \delta=0.05 ; r=0.05 ; v=3
$$$$
\mathrm{A}=6.41 \mathrm{e}-005 ; \mathrm{B}=1 ; \mathrm{C}=1 ; \mathrm{D}=0.0400641
$$

$$
\mathrm{E}=0.0175 ; \mathrm{F}=0.53 ; \mathrm{G}=6 ; \mathrm{H}=0.065
$$

